\title{
THE INFLUENCE OF ORGANIZATIONAL CLIMATE, TRANSFORMATIONAL LEADERSHIP, AND WORK MOTIVATION ON TEACHER JOB PERFORMANCE
}

\author{
Kartini*, Bedjo Sujanto**, Mukhneri Mukhtar*** \\ Ministry of Religious Affairs of the republic of Indonesia \\ State University of Jakarta \\ State University of Jakarta \\ kurnia2727@yahoo.com \\ bedjosujanto@unj.ac.id \\ mukhnerimukhtar@unj.ac.id
}

\begin{abstract}
This research aimed at investigating the influence of organizational climate, transformational leadership, and work motivation on teacher job performance at Pondok Modern Tazakka, Batang - Central Java.The research using quantitative approach with survey method. Amount of the samples in this research are 55 teachers that selected randomly. The data were analyzed by using descriptive statistics and inferential statistic using path analysis. (1) organizational climate have positive direct effect on teacher performance with path coefficient (pyl) $=0,257$ and $t$-count 2,963> t-table 1,684; (2) transformational leadership have positive direct effect on teacher performance with path coefficient $(p y 2)=0,489$ and $t$-count $5,164>t$-table 1,684, (3) work motivation have positive direct effect to teacher performance with path coefficient (py3) = 0,261 and t count 2,42> t-table 1,684, (4) organizational climate have positive direct effect $(p 31)=$ 0.391 and t-count 3.990>t-table 1.684, and (5) transformational leadership have a direct positive effect on work motivation with path coefficient $(p 32)=0.526$ and $t$-count $5,376>t$ - table 1,684 . The Conclusion is organizational climate, transformational leadership, and work motivation have a direct effect on teacher job performance. Organizational climate and transformational leadership also have a direct effect on teacher work motivation. Therefore to improve teacher job performance, organizational climate, transformational leadership, and work motivation must be considered to be improved.
\end{abstract}

Keywords: Organizational Climate, Transformational Leadership, Work Motivation, and Job Performance.

Creativity thinking leadership boarding school is more likely to kyai as a central figure. Creativity thinking and innovative attitude kyai actually not be separated from several factors, including vision and mission kyai itself and a sense of deep fear of new ideas that are considered to be misleading and bring the community pondok pesantren towards the worse. Pondok Pesantren which formerly the teaching system and its teaching materials focused on the religious sciences, began to develop by accommodating the curriculum elements of the national education system. The demands of the education system in Indonesia have required the pesantren to follow or equalize its standards with the national education curriculum. important because of the ability it has from education outside the pesantren. Generally most of the boarding schools have problems associated with teachers / ustadz which impact on low performance, for example:

First, the condition of teachers / religious teachers in the pesantren has not been treated the same as the teachers in formal schools recognized by the government. Secondly, the existence of teachers / religious teachers in pesantren has not been maximized, especially in traditional boarding schools or salafiyah. The teacher / ustadz is still considered as a student who is a teacher / ustadz under the control of kyai and still in the category of studying (thalabul ilmi), while the teaching function which they run is only limited to the kyai (khadimun lil shaykh). Thirdly, the services and 
facilities for teachers / teachers are not yet maximal, for example there are still many boarding schools in the food service for teachers / ustadz are not paid attention, or facilities for bathing and washing, all equated with the other santri, even though they serve 24 hours to take care of santri. Fourth, economic empowerment that has not maximized in pesantren, whereas with the potential of economic development is very large can provide additional source for welfare of teachers / ustadz. Fifth, the weakness of human resource development, in this case many teachers / cleric in boarding school has not maximized in terms of educational qualifications and competence. Various problems in pesantren as mentioned above, demands the government to immediately make regulations, especially about teachers / religious teachers related to the qualifications of education and competence. Government regulation as one effort to improve and develop quality education through improvement of teacher quality which impact on teacher performance.

The performance of teachers in boarding school is one of the interesting variables for the author thoroughly, because quality education can not be separated from the role of teachers in teaching and learning process. Performance of teachers who have not been optimal due to climatic conditions of pesantren organizations that have not been conducive. Pondok Modern Tazakka which stands on the land area of 9.8ha, located in Sidayu Village District Bandar Batang Central Java. This educational institution was initiated by three brothers, namely: Anang Rikza Masyhadi, Anizar Masyhadi and Anisia Kumala Masyhadi. The mission that was initiated by the three is to establish an Islamic educational institution, where the younger generation can gain knowledge, add insight and taste education system and teaching adequately. The principles underlying the development of Tazakka Modern Pondok is the creation of human resources who believe and piety, insightful, knowledgeable, and berakhlakul karimah.

In this case, the researcher wants to study and investigate whether the organizational climate, transformational leadership and work motivation of all elements in Pondok Modern Tazakka have a direct effect on the teacher's daily performance. In addition, teacher participation in planning, implementation, control and evaluation of education can promoting quality improvement and relevance as well as improving the effectiveness and efficiency of education management. High teacher performance is a critical determinant of the success of education. High teacher performance can be seen from the products produced such as Education Unit Level Curriculum (KTSP), Learning Implementation Plan (RPP), props, questions, and so on.

\section{Performance}

Performance is the most widely studied topic in various fields, such as management, industrial psychology, organizational behavior, and human resource management. One of the most widely referred performance concepts of Campbell as quoted Colquitt, LePine and Wesson, (2015: 32-33) is, "job performance is the value of the set of employee behaviors that contribute, either positively or negatively, to organizational goals accomplishment ". The concepts that are not much different are presented by Jex and Britt, (2008: 96) "Performance is all employee behavior in work or at work. Landy and Conte, (2013: 157) also emphasize the concept of performance about behaviors relevant to organizational goals, "job performance is actions or behaviors relevant to the organization's goals; measured in terms of each individual's proficiency ". Performance is the action or behavior that is relevant to realize the objectives of the organization measured refers to the expertise of each individual. Similarly to the concept expressed by Hanson and Borman, (2014: 143) "job performance is defined as the behavior that is relevant to the organization's goals and that can be measured in terms of the individual's contribution to organizational effectiveness". Performance refers to behaviors that are relevant to organizational goals and can be measured by their contribution to organizational effectiveness.

Another understanding of the performance concept is expressed by Motowilldo, (2003: 39) "job performance is defined as the total expected value to the organization of the discrete behavioral episodes that an individual carries out over a standard period of time. Byars and Rue explain, "job performance defined as the degree of accomplishment of the task that make up an employees job. It 
reflects how well an employee is fulfilling the requirements of a job ". Performance is understood as the degree of completion of tasks that employees work as a reflection of how well an employee meets the job requirements.

Based on the above description, it can be synthesized that performance is the performance of a person or group of people in completing tasks that are in charge and responsibility in order to achieve educational objectives measured by indicators: the teacher's understanding of the tasks that must be implemented, in completing the tasks, the results of the implementation of teacher tasks, and the benefits of the implementation of teacher duties for the success of education.

\section{Climate Organization}

Harrison and Shirom in Armstrong, (2012: 127) "organizational climate refers to 'members' perceptions of organizational features such as decision making, leadership and norms about work". Forehand and Glimer cited Saha, (2006: 396) provide an explanation of the organizational climate as follows: Organization climate is the set of characteristic that describe an organization and that (1) distinguishes the organization from other organization, (2) are relatively enduring over time, and (3) influence the be havior of the people in the organization. Taguiri as quoted by Furnham, (1997: 580) describes the organizational climate as follows: Organizational climate is a relatively enduring quality of the internal environment of an organization that is experienced by its members, (b) influences their behavior, and ( c) can be described in terms of the values of a particular set of characteristics (or attributes) of the organizations.

Moran and Volkwein cited Kusluvan, (2003: 458) describes the concept of organizational climate as follows: Organizational climate as well as relative enduring characteristics of an organization which distinguishes it from other organization; and (a) embodies members collective perceptions about their organization with respect to such dimensions as autonomy, trust, cohesiveness, support, recognition, innovation, and fairness; (b) is produced by members interaction; (c) serves as a basis for interpreting the situation; (d) reflects the prevalent norms, values and attitudes of the organization's culture, and (e) acts as a source of influence for shaping behavior.

Organizational climate reveals, "Organizational climate is a set of properties of the work environment, perceived, directly or indirectly by the employees, that assumes to be a major force in influencing employee behavior." Ivancevich, Konopaske, Matteson, (2014: 554) This concept has the meaning that the organizational climate is a set of attributes of the work environment perceived by the worker both directly and indirectly and that is what is assumed to be a major force affecting the behavior of the workers.

Organizational climate is the internal environmental condition of the organization that survives relatively long and affects members of the organization in performing its duties and responsibilities with indicators: patterns of interaction between employees, communication systems within the organization, the treatment of leadership to subordinates, the physical situation of the organization environment, and a conducive and productive climate.

\section{Transformational leadership}

Hughes, Ginnet, and Curphy, (2012: 5) "leadership as the process of influencing an organized group toward accomplishing its goals is fairly comprehensive and helpful". Lussier and Achua, (2010: 6) "leadership is the influencing process of leaders and followers to achieve organizational objectives through change". Robbins and Judge, (2014: 178) describe the concept of leadership, "leadership is the ability to influence a group toward the achievement of a vision or set of goals". While DuBrin, (2013: 2) states, "leadership as the ability to inspire confidence and support among the people who are needed to achieve organizational goals. Bass and Riggio, (2006: 4) describe the concept of transformational leadership: 
Transformational leaders motivate others to do more than they thought possible. They set more challenging expectations and typically achieve higher performances. Transformational leaders also tend to have more committed and satisfied followers. Moreover, transformational leaders empower followers and pay attention to their individual needs and personal development, helping followers to develop their own leadership potential.

Transformational leaders are motivating others to do more than they want and more often than they might think. Leaders set challenging expectations and usually achieve higher performance. Transformational leaders tend to have more committed and satisfying followers. Transformational leaders also empower followers and pay attention to their individual needs and personal development, helping followers develop their own leadership potential.

Transformational leadership is the process of influencing subordinates by giving inspiration to prioritize organizational progress rather than personal interests and performing responsibilities more than expected in order to achieve organizational goals measured by indicators: the vision and mission of a leader, how to make decisions, members, and direction of members of the organization

\section{Work motivation}

George and Jones, (2012: 157) "work motivation is the psychological forces within a person that determine the direction of the person's behavior in an organization, effort level, and persistence in the face of obstacles. Smith, (2013: 613) in his concept also describes the meaning of the following motivation: Work motivation refers to the force (internal or external) that drives individuals to engage in purposeful behaviors related to their job. Work motivations energizes a person to engage in a task that is complete. A similar opinion is expressed by Pinder, (2008: 11) "work motivation is a set of energetic forces that originate both within as well as beyond an individual's being, to initiate work-related behavior, and its determinate direction, direction, intensity, and duration ". Work motivation is a series of energetic forces that originate both within and beyond the existence of the individual, to initiate work-related behavior, and to determine the shape, direction, intensity, and duration. Muchinsky, (2006: 381), subsequently lays out related to the direction, intensity, and duration are as follows: First, direction addresses the choice of activities we make in expending effort. That is, we might choose to work diligently at some tasks and not at others. Second, intensity implies we have the potential to exert various levels of effort, depending on how much we need to expend. Third, duration reflects the persistence of motivation over time, as opposed to a one-time choice between courses of action (direction) or high levels of effort aimed at a single task (intensity). A comprehensive understanding of work motivation requires an integration of these concepts.

Kanfer, Chen, and Pritchard, (2008: 3-4) disclose "work motivation defined as the set of processes of intentions to allocate personal resources across a range of possible actions." Then Coon and Mitterer related motivations to explain, "Motivation is internal processes that initiate, sustain, direct, and terminate activities" motivation is an internal process that initiates, maintains, directs, and terminates activities. work motivation is a change of energy in a person as a source of strength in carrying out its duties or responsibilities so that the desired goals can be achieved optimally measured through indicators of the implementation of tasks or responsibilities, fulfillment needs, business intensity, empathy and goals.

\section{METHOD}

This research is conducted by survey method with path analysis approach. The population of this study were teachers at Pondok Modern Tazakka. The number of samples is 63 teachers. this study was collected with a tool (instrument) in the form of questionnaires or research questionnaires. 
Research questionnaire development is usually done indirectly, either in the form of test or non-test (scale) which is arranged based on the indicators of the theory building of each variable studied.

Method and technical analysis that will be used, hence hypothetical model of causal relationship between variables as presented in the picture below.

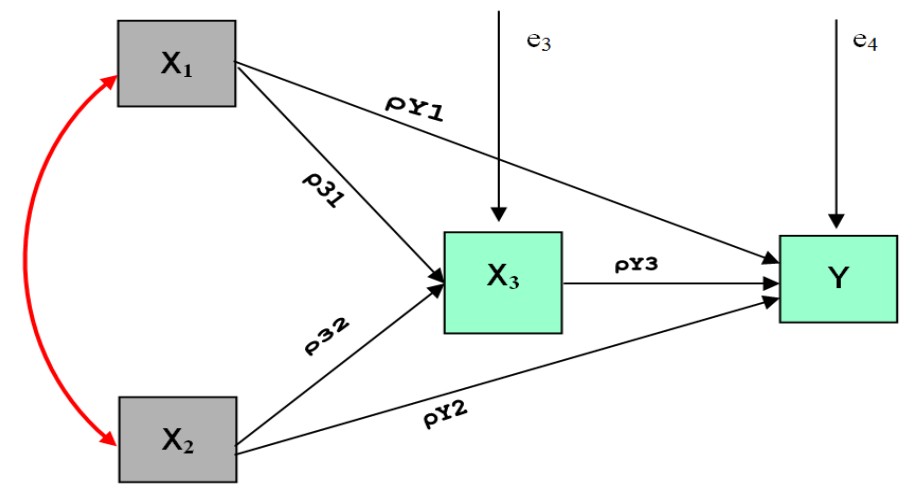

Picture: 3.1

Hypothetical Model of Causal Relation between Variables

Description:

$\mathrm{X}_{1} \quad$ : Organizational Climate Variables

$\mathrm{X}_{2} \quad$ : Variables of Transformational Leadership

$\mathrm{X}_{3} \quad$ : Variable Motivation Work

$\mathrm{Y} \quad$ : Performance Variables

$\rho_{\mathrm{Y} 1}$ : Path coefficient of influence $\mathrm{X} 1$ to $\mathrm{Y}$

$\rho_{\mathrm{Y} 2}:$ The path coefficient of $\mathrm{X} 2$ effect on $\mathrm{Y}$

$\rho_{\mathrm{Y} 3}:$ The path coefficient of $\mathrm{X} 3$ effect on $\mathrm{Y}$

$\rho_{31}$ : Path coefficient of influence $\mathrm{X} 1$ to $\mathrm{X} 3$

$\rho_{32}$ : Path coefficient of influence X2 to X3

\section{RESULTS}

The variables in this study include performance (Y), organizational climate (X1), transformational leadership (X2), and work motivation (X3). Descriptive statistics include minimum, maximum, range, average, mean, standard, standard deviation, variance and total scores and frequency distribution tables and histograms.

The above normality estimation error results can then be summarized in Table 4.9 below.

Table 4.9 Summary Of Normality Test Results

\begin{tabular}{|l|c|c|l|}
\hline Estimated Error & L.Count & L.Table & \multicolumn{1}{|c|}{ Conclusion } \\
\hline $\begin{array}{l}\text { 1. performance of } \\
\text { teacher (Y) over } \\
\text { organizational climate } \\
\text { (X1) }\end{array}$ & 0,100 & 0,119 & $\begin{array}{l}\text { comes from a normally } \\
\text { distributed population }\end{array}$ \\
\hline $\begin{array}{l}\text { 2. performance of } \\
\text { teacher (Y) on } \\
\text { transformational } \\
\text { leadership (X2) }\end{array}$ & 0,075 & 0,119 & $\begin{array}{l}\text { comes from a normally } \\
\text { distributed population }\end{array}$ \\
\hline $\begin{array}{l}\text { 3. teacher performance } \\
\text { (Y) for work } \\
\text { motivation (X3) }\end{array}$ & 0,066 & 0,119 & $\begin{array}{l}\text { comes from a normally } \\
\text { distributed population }\end{array}$ \\
\hline
\end{tabular}




\begin{tabular}{|c|c|c|l|}
\hline $\begin{array}{l}\text { 4. work motivation (X3) } \\
\text { over organizational } \\
\text { climate (X1) }\end{array}$ & 0,079 & 0,119 & $\begin{array}{l}\text { comes from a normally } \\
\text { distributed population }\end{array}$ \\
\hline $\begin{array}{l}\text { 5. work motivation (X3) } \\
\text { for transformational } \\
\text { leadership (X2) }\end{array}$ & 0,080 & 0,119 & $\begin{array}{l}\text { comes from a normally } \\
\text { distributed population }\end{array}$ \\
\hline
\end{tabular}

From the results of testing the requirements of the analysis obtained the conclusions of data derived from the population that distributed normality and have a linear pattern, thus meeting the requirements for inferential statistics. Therefore, further path analysis can be carried out (path analysis). Calculation of path analysis using SPSS Version 22 and LISREL 8.8 software. In the process of calculating path analysis used input correlation coefficient. The correlation coefficient matrix which shows the relationship between variables can be seen in table 4.16.

Table 4.16 matrix correlation coefficient relationship between variables

\begin{tabular}{|l|c|c|c|c|}
\hline \multicolumn{1}{|c|}{ Variable } & $\mathrm{X} 1$ & $\mathrm{X} 2$ & $\mathrm{X} 3$ & $\mathrm{X} 4$ \\
\hline $\begin{array}{l}\text { 1. } \begin{array}{l}\text { organizational climate } \\
\text { (X1) }\end{array} \\
\text { 2. } \begin{array}{l}\text { transformational } \\
\text { leadership (X2) }\end{array}\end{array}$ 0,576 & 1,000 & & \\
\hline 3. work motivation (X3) & 0,694 & 0,752 & 1,000 & \\
\hline 4. Performance (X4) & 0,720 & 0,833 & 0,807 & 1,000 \\
\hline
\end{tabular}

From correlation coefficient matrix is seen correlation coefficient obtained from the smallest is the relationship between organizational climate (X1) with transformational leadership (X2) = 0.576, until the largest relationship between transformational leadership (X2) with performance (Y) of 0.833 .

Furthermore, the calculation of path coefficients for each structural equation is done. In this research model consists of two structural equations. The first structural equation is organizational climate (X1), transformational leadership (X2), and work motivation (X3) on performance (Y). Result of path coefficient calculation for structural equation 1 with SPSS program got result as seen in table 4:17.

Table 4.17. Coefficient of Climate Influence Line Organization, Transformational Leadership, and Work Motivation on Teacher Performance

Coefficients

\begin{tabular}{|l|c|c|c|c|c|}
\hline \multirow{2}{*}{ Model } & \multicolumn{2}{|c|}{$\begin{array}{c}\text { Unstadndardlized } \\
\text { Coefficients }\end{array}$} & $\begin{array}{c}\text { Standardlized } \\
\text { Coefficients }\end{array}$ & \multirow{2}{*}{$\mathrm{t}$} & Sig \\
\cline { 2 - 5 } & $\mathrm{B}$ & $\begin{array}{c}\text { Std. } \\
\text { Erros }\end{array}$ & Beta & & .237 \\
\hline $1 . \quad$ (Constant) & 10,980 & 9,171 & & 1,197 & .005 \\
\hline $\begin{array}{l}\text { organizational } \\
\text { climate }\end{array}$ & .215 & .073 & .257 & 2.963 & .000 \\
\hline $\begin{array}{l}\text { Transformational } \\
\text { Leadership }\end{array}$ & .465 & .090 & .489 & 5.164 & .019 \\
\hline work motivation & .213 & .088 & .261 & 2.424 & \\
\hline
\end{tabular}


The second structiral equation is organizational climate (X1) and transformational leadership (X2) on work motivation (X3). The result of the path coefficient calculation for the second structural equation is shown in Table 4.18.

Table 4.18. Coefficient of Climate Influence Line of Organization and Transformational Leadership on Work Motivation

Coefficients

\begin{tabular}{|l|c|c|c|c|c|}
\hline \multirow{2}{*}{ Model } & \multicolumn{2}{|c|}{$\begin{array}{c}\text { Unstadndardlized } \\
\text { Coefficients }\end{array}$} & $\begin{array}{c}\text { Standardlized } \\
\text { Coefficients }\end{array}$ & \multirow{2}{*}{$\mathrm{t}$} & Sig \\
\cline { 2 - 5 } & $\mathrm{B}$ & Std. Erros & Beta & & .119 \\
\hline $1 . \quad$ (Constant) & $-22,359$ & 14,108 & & $-1,585$ & .000 \\
\hline $\begin{array}{l}\text { organizational } \\
\text { climate }\end{array}$ & .399 & .100 & .391 & 3.990 & .000 \\
\hline $\begin{array}{l}\text { Transformational } \\
\text { Leadership }\end{array}$ & .611 & .114 & .526 & 5.376 &. \\
\hline
\end{tabular}

From the result of the structural equation above, we can make the following path diagram:

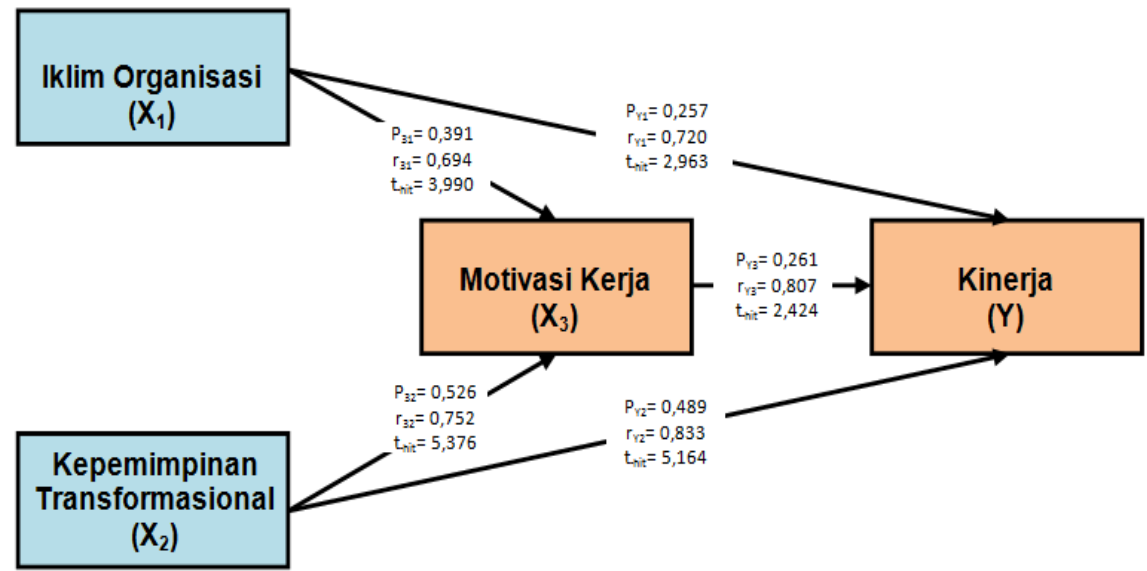

Gambar 4.5. Koefisien Jalur dan T-hitung Pengaruh Iklim Organisasi, Kepemimpinan Transformasional, dan Motivasi Kerja terhadap Kinerja Guru

Explanation of the results of path analysis for testing the research hypothesis is described as follows:

\section{Direct Influence of Organizational Climate on Performance}

The first hypothesis in this study are: There is a positive direct effect of organizational climate on teacher performance. Statistically it can be written:

$$
\begin{aligned}
& \mathrm{H}_{\mathrm{o}}: \beta_{\mathrm{Y} 1} \leq 0 \\
& \mathrm{H}_{1}: \beta_{\mathrm{Y} 1}>0
\end{aligned}
$$

From result of calculation of path coefficient direct influence of organizational climate to teacher performance obtained result $\rho Y 1=0,257$ with t-hitung $=2,963$. While the price of t-table for degrees of freedom $(\mathrm{dk}) 53$ and the level of trust is 1.684 . The results obtained show the price of $\mathrm{t}$ count> t-table, which means reject Ho. Thus it can be concluded that there is a positive direct effect of organizational climate on performance. This result means that a conducive organizational climate will lead to improved teacher performance in Pondok Modern Tazakka.

\section{Direct Influence of Transformational Leadership to Performance}

The second hypothesis of this study are: There is a direct positive influence of transformational leadership on performance. In the statistical formulation can be stated:

$$
\begin{aligned}
& \mathrm{H}_{\mathrm{o}}: \beta_{\mathrm{Y} 2} \leq 0 \\
& \mathrm{H}_{1}: \beta_{\mathrm{Y} 2}>0
\end{aligned}
$$


The result of path coefficient calculation of direct influence of transformational leadership on performance is obtained result $\rho \mathrm{Y} 2=0,489$ with $\mathrm{t}$-count value $=5,164$. The $\mathrm{t}$-table price for degrees of freedom (dk) 53 and the level of trust is 1.684 . The result shows that the price of t-arithmetic $>t-$ table, which means reject Ho. Thus it can be concluded that there is a positive direct effect of transformational leadership on performance. These results indicate that transformational leadership played effectively will lead to improved teacher performance in Pondok Modern Tazakka.

\section{The Direct Influence of Work Motivation on Performance}

The third hypothesis in this study are: There is a direct positive influence of work motivation on performance. Statistically can be stated:

$$
\begin{aligned}
& \mathrm{H}_{\mathrm{o}}: \beta_{\mathrm{Y} 3} \leq 0 \\
& \mathrm{H}_{1}: \beta_{\mathrm{Y} 3}>0
\end{aligned}
$$

The result of path coefficient calculation of direct effect of work motivation on teacher performance obtained result $\rho Y 3=0,261$ with t-hitung $=2,424$. While the price of $\mathrm{t}$-table for degrees of freedom (dk) 53 and the level of trust is 1.684 . The results obtained show that the price of $t-$ arithmetic> t-table, so reject Ho. Thus the conclusion there is a direct positive influence of work motivation on teacher performance. These results suggest that high work motivation will lead to improved teacher performance in Pondok Modern Tazakka.

\section{Direct Influence of Climate Organization on Work Motivation}

Fourth hypothesis in this research are: There is positive direct effect of organizational climate to work motivation. The statistical formula is:

$$
\begin{aligned}
& \mathrm{H}_{\mathrm{o}}: \beta_{31} \leq 0 \\
& \mathrm{H}_{1}: \beta_{31}>0
\end{aligned}
$$

Result of calculation of path coefficient direct influence of organizational climate to work motivation obtained result $\rho 31=0,391$ and $t$-hitung $=3,990$. While the price of $\mathrm{t}$-table for degrees of freedom (dk) 53 and $95 \%$ confidence level $\square(\square=5 \%$ ) is 1.684 . The results obtained show that the price of t-arithmetic>t-table, so reject Ho. Thus the conclusion is that there is a positive direct effect of organizational climate on work motivation. These results mean that a conducive organizational climate will lead to an increase in teacher work motivation in Pondok Modern Tazakka.

\section{Direct Influence of Transformational Leadership on Work Motivation}

The fifth hypothesis in the study are: There is a positive direct effect of transformational leadership on work motivation. which in the statistical formula is:

$$
\begin{aligned}
& \mathrm{H}_{\mathrm{o}}: \beta_{31} \leq 0 \\
& \mathrm{H}_{1}: \beta_{31}>0
\end{aligned}
$$

The result of path coefficient calculation of direct influence of transformational leadership on work motivation obtained result $\rho 32=0,526$ and price $\mathrm{t}$-count $=5,376$. While the price of $\mathrm{t}$-table for degrees of freedom (dk) 53 and $95 \%$ confidence level $(\square=5 \%)$ of 1.684 . The results obtained show the price t-count> t-table, so reject Ho. Thus the conclusion is that there is a positive direct effect of transformational leadership on work motivation. This means that transformational leadership that is played effectively will lead to an increase in teacher work motivation in Pondok Modern Tazakka.

\section{DISCUSSION}

\section{The Influence of Organizational Climate on Performance}

Climate organization is an environmental condition that has a direct influence on the performance of members of the organization, where all elements in the organization perform tasks and responsibilities in order to achieve organizational goals. Climate of the school organization consists of dimension of relationship, dimension of growth or personal development, dimension of change and improvement of system, dimension of physical environment. A good organizational 
climate and accepted by all members of the organization, and preserved and preserved, will encourage a harmonious atmosphere, a safe and enjoyable school environment to support the implementation of the duties and responsibilities of each member of the organization.

Organizational climate affects performance because its existence affects individual behavior, where behavior is an integral part of performance. This is as stated by Gilmer in Ehrhart, Schneider and Macey "influence of the behavior of the organization, 2) the relative influence of the organization of the organization, people in the organization. This opinion states that the organizational climate is one of the distinguishes one organization and the other that can be felt if one enters into it and affect the behavior of people who are in the organization. Theoretically, the effect of organizational climate on performance is explained by Dreyfus, "perceptions of a positive organizational climate are related to job satisfaction in work organizations, unit effectiveness in a military setting and employee performance." This confirms that the perception of a positive organizational climate is wrong only bekaitan with performance.

Thus the results of this study support theories and results of previous research on the existence of organizational climate influences on performance, especially in the educational environment.

\section{The Influence of Transformational Leadership to Performance}

The findings in this study indicate that transformational leadership has a direct positive effect on teacher performance in Pondok Modern Tazakka. Transfornational leadership is a way of using power and influence to direct members of the organization to actively participate in achieving organizational goals. Effective leadership can be demonstrated by means of organizational resource management to achieve organizational goals. Therefore, leadership in an organization should be based on various indicators, such as visionary, democratic, honest and fair, transparent, accommodative, employee oriented or outcomes, effective and efficient in the utilization of organizational resources. While performance is related to all the performance of the school's ability in the implementation of its tasks and functions, especially in providing education services in accordance with the needs of the users of educational services so that school objectives can be achieved optimally. Performance is not only measured from its output, but must be measured from the input and process. Therefore, performance is highly dependent on the effectiveness of the management and utilization of school resources so that school processes and objectives can be implemented effectively and efficiently. Meanwhile, the principal's function is to manage, direct, and mobilize school resources to function effectively and efficiently in order to achieve school goals (education).

Transformational, visionary, democratic, fair and honest, transparent, accommodative, and subordinate-oriented leadership can encourage effective and efficient performance. Nevertheless, authoritarian, even authoritarian, leadership is sometimes necessary to improve organizational performance. This is as confirmed Ronquillo (2011: 349.) follows:

Transformational leadership involves the motivation of employees and members to perform normal expectations for meeting the organization's mission and for achieving organizational goals. It inspires staff and members to put aside personal self interest for the common good of the organization and to have confidence in their ability to achieve the extraordinary challenges before them.

Transformational leadership involves the motivation of employees and members of the organization to perform normal expectations to fulfill the organization's mission and realize organizational goals. Such conditions inspire subordinates to set aside personal interests for the common good of the organization and have confidence in their ability to achieve extraordinary challenges from before. Another opinion that shows the influence of transformational leadership on 
performance is stated Colquitt, LePine and Wesson (2013: 469): Transformational leadership has a moderate positive effect on Performance. Employees with transformational leaders tend to have higher levels of Task Performance. They are also likely to engage in Citizenship Behavior. Less is known about the effects of transformational leadership on Counterproductive Behavior.

The explanation shows that transformational leadership has a moderate effect on performance. Employees with transformational leadership tend to have higher performance tasks. Previous research conducted by Thamrin (2012: 566-572.) Also shows that transformational leadership has a significant effect on performance. The research results of Yehezkiel (2013) also showed a positive influence between leadership on employee performance at UPTD development of productivity of Disnakertrans area of East Kalimantan Province. Similarly, research Khoirusmadi (2014) also shows transformational leadership affect the performance. Thus the results of research increasingly support and confirm the theory and previous research on the important role of transformational leadership in improving performance, especially in the educational environment.

\section{Influence Work Motivation on Performance}

The results of this study prove that work motivation has a direct positive influence on teacher performance. These results provide insight that strong work motivation will have an impact on teacher performance in Pondok Modern Tazakka. Therefore, if the work motivation of teachers decreased, will result in decreased performance of teachers.

Motivation of work as energy changes in each individual is a determinant of high performance. The stronger the work motivation of teachers and employees in the implementation of tasks and responsibilities, the higher the performance. Thus, work motivation is suspected to have a direct positive effect on performance. The existence of a significant influence of motivation factors on performance can be understood and relevant to theories used as a theoretical reference and relevant to the results of previous research. One theory that can be used to explain the influence of motivational factors on employee performance is the theory of Wyatt's Performance Formula. The Wyatt's Performance Formula theory states that $\mathrm{P}=\mathrm{f}(\mathrm{a} . \mathrm{M})$. The formula can be read that performance (Performance $=\mathrm{P}$ ) is a function $(\mathrm{f})$ of the ability (ability $=\mathrm{a}$ ) and motivation (motivation $=\mathrm{m}$ ). (Atmosoeprapto 2000: 41) This means either the bad performance of one of which is influenced by high and low motivation. This formula also shows that the effort to improve performance must involve motivation factor.

These conditions can occur because the motivation is a source of energy for individuals to perform activities. According to Kanfer cited by George and Jones (2012: 157), work motivation is defined as: the psychological forces within a person that determine the direction of the person's behavior in an organization, effort level, and persistence in the face of obstacles. This means that motivation is a psychological force within a person that determines the direction of one's behavior within the organization, the level of effort and perseverance in the face of obstacles.

Motivation is a concept to describe the impulses in the individual, which ultimately drive and direct the behavior of the individual concerned. Motivation is also very important to improve the enthusiasm or morale of subordinate work that ultimately boils down to the improvement of individual performance. Thus the higher a person's willingness to do the job, the better the work that can be achieved. The influence of motivation on performance is affirmed by Colquitt, LePine and Wesson (: 185) .as the following:

Motivation has a strong positive effect on Job Performance. People who experience higher levels of motivation tend to have higher levels of Task Performance. Those effects are strongest for self-efficacy/competence, followed by goal difficulty, the valence-instrumentality-expectancy combination, and equity. Less is known about the effects of motivation on Citizenship and Counterproductive Behavior, though 
equity has a moderate positive effect on the former and a moderate negative effect on the latter.

The explanation confirms that motivation has a positive and strong influence on performance. People who experience higher motivation will have higher levels of higher performance. The results of Rasyid's (2013), Mahardhika (2014) and Cahyono (2014) studies also provide evidence that work motivation influences performance. Thus the results of research increasingly reinforce the theory and the results of previous research on the importance of work motivation in affecting performance.

\section{The Influence of Organizational Climate on Work Motivation}

The findings in this study indicate that the organizational climate has a direct positive effect on teacher work motivation in Pondok Modern Tazakka. This result means that a conducive organizational climate will have an impact on improving teacher work motivation. Thus, an unfavorable organizational climate will degrade teachers' work motivation in Pondok Modern Tazakka. This confirms that a conducive organizational climate is needed in order to encourage teachers to be more active in work. Organizational climates indicate an environmental condition that has a direct influence on the performance of organizational members, in which all elements of the organization perform tasks and responsibilities in order to achieve organizational goals. While the motivation of work is the driving force or activator originating from within or from outside of a person or organization to carry out a given work assignment or the responsibility. Conducive and consistent organizational climate consistently and consistently can be a source of stimulation for the development of work motivation in a person in carrying out duties or responsibilities.

The influence of organizational climate on work motivation can be understood given the existence of organizational climate can influence the behavior of members of the organization. It was as revealed by Ivancevich, Konopaske and Matteson (2008: 528), "organizational climate is a set of properties of the work environment, perceived, directly or indirectly by the employees, that assumes to be a major force in influencing employee behavior." This opinion holds that the organizational climate is a set of qualities of the work environment perceived by workers both directly and indirectly and that is what is assumed to be a major force affecting workers' behavior. Emergent behaviors can be a reflection of the work motivation of organizational members. Litwin and Stringer in Dotlich (2009: 229). also pointed out.

\section{Organizational climate, defined as the collection and pattern of environmental determinants of aroused motivation, stimulated the need for achievement, the need for affiliation, and the for power, thre most important and most studied social motives.}

This opinion shows that organizational climate as a collection and pattern of the environment is the determinant of the emergence of motivation, whether achievement motivation, motivation of affiliation, and power motivation which is the most important and most learned form of motivation. Previous studies conducted by Gok also proved that organizational climate has a positive effect on motivation.

\section{The Influence of Transformational Leadership on Work Motivation}

Hypothesis testing in this study proves that transformational leadership has a direct positive effect on teacher work motivation in Pondok Modern Tazakka. These results provide guidance that transformational leadership that is effectively played by the leadership will increase teacher work motivation. These results suggest that transformational leadership is an important determinant of improving teacher work motivation in the Tazakka Modern Pondok neighborhood. Therefore, if 
transformational leadership does not work effectively, it will have an impact on the decline in teacher work motivation.

Transformational leadership is a way of using power and influence to direct members of an organization to actively participate in achieving organizational goals. Transformational leadership in an organization is based on various indicators, such as visionary, democratic, honest and fair, transparent, accommodative, employee / subordinate oriented as well as to results, effective and efficient in the utilization of organizational resources. While the motivation of work relates to the driving force or activator originating from within or from outside of a person or organization to carry out a given work assignment or the responsibility.

Associated with the transformational leadership of Bass and Riggio (2006: 4) explains:Transformational leaders motivate others to do more than they thought possible. They set more challenging expectations and typically achieve higher performances. Transformational leaders also tend to have more committed and satisfied followers. Moreover, transformational leaders empower followers and pay attention to their individual needs and personal development, help followers to develop their own leadership potential.

Leaders set challenging expectations and usually achieve higher performance. Transformational leaders also tend to have more committed and satisfying followers. In addition, transformational leaders empower followers and pay attention to their individual needs and personal development, helping followers develop their own leadership potential. With such conditions it is clear that transformational leadership will be able to generate work motivation.

\section{CONCLUSION}

With reference to the results of the analysis and discussion in the previous chapter, the conclusions of this study are as follows:

Organizational climate has a positive direct effect on teacher performance in Pondok Modern Tazakka. This result gives the meaning that conducive organizational climate will cause the improvement of teacher performance in Pondok Modern Tazakka, and on the other hand the unfavorable organizational climate will result in lower teacher performance. Transformational leadership has a positive direct influence on teachers' performance motivation in Pondok Modern Tazakka. This means that transformational leadership played effectively will lead to improved teacher performance in Pondok Modern Tazakka, and otherwise ineffective transformational leadership will result in lower teacher performance. Work motivation has a positive direct effect on teacher performance in Pondok Modern Tazakka. This means that strong teacher work motivation will lead to improved teacher performance in Pondok Modern Tazakka, and low work motivation will result in lower teacher performance. Organizational climate has a positive direct effect on teacher work motivation in Pondok Modern Tazakka. This means that a conducive organizational climate will lead to an increase in teacher motivation in Pondok Modern Tazakka, and on the other hand an unfavorable organizational climate will result in lower teacher motivation. Transformational leadership has a direct positive influence on teacher work motivation in Pondok Modern Tazakka. This means that transformational leadership played effectively will lead to an increase in teacher work motivation in Pondok Modern Tazakka, and otherwise ineffective transformational leadership will result in lower teacher work motivation.

\section{REFERENCES}

Adrian Furnham. (1997). The Psychology of Behaviour at Work: The Individual in the Organization. Hove Eas Sussex: Psychology Press.

Andrew J. DuBrin. (2013). Leadership: Research Findings, Practice, and Skills. Mason: SouthWestern.

Bernard M. Bass dan Ronald E. Riggio. (2006). Transformational Leadership. New Jersey: Lawrence Erlbaum Associates. 
Bass, Bernard M. dan Ronald E. Riggio. (2006) Transformational Leadership, New Jersey: Lawrence Erlbaum Associates, Inc.,

Bhawana Saun, Sanjeevni Gangwani, dan Sangeeta Jain. (2016). "Impact of Organizational Climate on Teacher's Motivation in Madhya Pradesh", International Journal of Management and Social Sciences Research (IJMSSR), Vol. 5, No. 9.

Craig C. Pinder. (2008). Work Motivation in Organizational Behavior. New York: Psychology Press.

David L. Dotlich, Peter C.Cairo, Stephen H. Rhinesmith, Ron Meeks. (2009). The 2009 Pfeiffer Annual: Leadership Development. San Francisco: John Wiley \& Sons.

Frank J. Landy dan Jeffrey M. Conte. (2013). Work in The $21^{\text {st }}$ Century: An Introduction to Industrial and Organizational Psychology. Mason: John Wiley \& Sons.

H. M. Thamrin. (2012). "The Influence of Transformational Leadership and Organizational Commitment on Job Satisfaction and Employee Performance", International Journal of Innovation, Management and Technology, Vol. 3, No. 5.

Jason A. Colquitt, Jeffery A. LePine dan Michael J. Wesson. (2015). Organizational Behavior: Improving Performance and Commitment in the Workplace. New York: McGraw-Hill Companies.

-------Jason A. Colquitt, Jeffery A. LePine dan Michael J. Wesson. (2013). Organizational Behavior: Improving Performance and Commitment in the Workplace. New York: McGraw-Hill Companies.

Jayantee Saha. (2006). Management and Organizational Behaviour. New Delhi: Excel Books.

J. M. Ivancevich, R. Konopaske dan M.T. Matteson. (2014). Organizational Behaviour and Management. New York: McGraw-Hill/Irwin.

-J. M. Ivancevich, R. Konopaske, M.T. Matteson. (2008). Organizational Behaviour and Management. New York: McGraw-Hill/Irwin.

Jennifer M. George dan Gareth R. Jones. (2012). Understanding and Managing Organizational Behavior. New Jersey: Pearson Prentice-Hall.

Jex, Steve M. and Thomas W. Britt, (2008). Psychology: A Scientist-Practitioner Approach, New Jersey: John Wiley \& Sons, Inc.,

John C. Ronquillo. (2011). Servant, Transformational, and Transactional Leadership, ed. Kathryn A. Agard. California: SAGE Publications.

Kiki Cahaya Setiawan. (2015). "Pengaruh Iklim Organisasi terhadap Kinerja Karyawan Level Pelaksana di Divisi Operasi PT. Pusri Palembang”, Jurnal Psikologi Islami, Vol. 1, No. 1.

Kisdarto Atmosoeprapto. (2000). Menuju SDM Berdaya dengan Kepemimpinan Efektif dan Manajemen Efisien. Jakarta: PT.Elex Media Komputindo.

Kusluvan, Salih. (2003). Managing Employee Attitudes and Behaviors in the Tourism and Hospitaility Industry, New York: Nova Science Publishers, Inc.,

Landy, Frank J. dan Jeffrey M. Conte. (2013). Work in The 21 $1^{\text {st }}$ Century: An Introduction to Industrial and Organizational Psychology, Mason: John Wiley \& Sons, Inc.,

Mary Ann Hanson dan Walter C. Borman. (2014). Citizenship Performance: An Integrative Review and Motivational Analysis, eds. Winston Bennett, Charles E. Lance, dan David J. Woehr. New York: Psychology Press.

Michael Armstrong. (2012). A Handbook of Human Resource Management Practice. London: Kogan.

P. M. Muchinsky. (2006). Psychology Applied to Work. Belmont CA: Wadsworth Thomson Learning.

Richard L. Hughes, Robert C. Ginnet, dan Gordon J. Curphy. (2012). Leadership: Enhancing The Lessons of Experience. New York: McGraw-Hill Company.

Robert N. Lussier dan Christopher F. Achua. (2010). Effective Leadership: Theory, Application, \& Skill Development. Ohio: Thomson South-Western.

Ruth Kanfer, Gilad Chen, dan Robert D. Pritchard (eds). (2008). The Three C's of Work Motivation: Content, Context, and Change. New York: Routledge.

Salih Kusluvan. (2003). Managing Employee Attitudes and Behaviors in the Tourism and Hospitaility Industry. New York: Nova Science Publishers. 
Sibel Gök. (2009). "A study on the influence of organizational climate on motivation of employees", Journal of Human Sciences, vol. 6, no. 2.

Stephan J. Motowidlo. (2003). Job Performance, edited by Walter C. Borman, Daniel R. Ilgen, and Richard J. Klimoski. New Jersey: John Wiley \& Sons.

Stephen P. Robbins dan Timothy Judge. (2014). Essential of Organizational Behavior. New Jersey: Pearson Prentice Hall.

Steve M. Jex and Thomas W. Britt. (2008). Psychology: A Scientist-Practitioner Approach. New Jersey: John Wiley \& Sons.

Vicki Smith (ed). (2013). Sociology of Work: An Encyclopedia. California: SAGE Publications.

Yehezkiel, Masjaya, dan Rosa Anggraeiny. (2013). "Pengaruh Kepemimpinan dan Iklim Organisasi Terhadap Kinerja Pegawai Pada UPTD Pengembangan Produktivitas Daerah Disnakertrans Provinsi Kalim antan Timur", eJournal Administrative Reform.

Yoav Vardi dan Ely Weitz. (2004). Misbehavior in Organizations: Theory, Research, and Management. New Jersey: LEA Publishers. 